what they were originally put there-viz., to carry the weight of the train, and not to ineffectually carry an electric current also. Such a system enormously diminishes the electrolytic corrosion of gas and water pipes ; and, since it is a system that has been designed by a celelsrated firm of consulting electrical engineers and carried out by a no less celebrated firm of electrical contractors, surely nobody suggests that it is in any sense impracticable.

It will be urged, however, that on that vast network of tramways lying between Uxbridge Road and Acton, Hammersmith and Hounslow, Kew and Richmond, \&c., which will shortly be worked electrically, two overhead insulated conductors are impossible, and we must adopt the Aınerican system. Yes, but what American system? The conduit system, for example, employed already for years in Washington, and of which some seventy miles now exist in New York, in which there are no overhead wires at all, but an insulated going and an insulated return conductor, both under the street? Or is all this too modern for England, and can we not project ourselves in advance of where America was several years ago, and must we resort to the old insulated trolley wire to take the current and the uninsulated rails to bring it back?

Why, only recently there was suggested, in one of the technical papers, a proposal to overcome all this difficulty in the case of street electric tramways by taking the current to the cars by means of an overhead trolley wire as hitherto, but using instead of the rails as the return conductor an insulated cable which was connected auto. matically with a car as it passed along and which, differing in potential from the earth by only a few volts, could not give rise to appreciable leakage to the ground. Will an insuperable barrier to a trial of such an English system be found in the fact that its parent, called "surface contact." was itself born of English parents in $188 \mathrm{I}$ ? Must it, like an opera singer of forty years ago, first adopt an Italian name before it will be accepted by a British public?

Already the Central London Railway Co. has given notice of an application to Parliament for powers to extend westward and eastward; every week now some new underground electric railway scheme blossoms forth for London, while in a few years electric tramways will doubtless be a common method of conveyance in this city. An urgent question, therefore, that London must ask itself to-day is-Does it want to preserve its gas and water pipes?

\section{AGRICULTURAL DEMONSTRATION AND} EXPERIMENT.

T $\mathrm{HE}$ issue by the Board of Agriculture of the "Annual Report on the Distribution of Grants for Agricultural Education and Research in the year 18991900." directs attention to a department of educational activity which was practically non-existent in the beginning of the present decade. From this it need not be inferred that there was no education in agriculture--both in the class-room and on the field-before this date. The work of Rothamsted, of our leading agricultural societies, and of certain agricultural colleges, is conclusive evidence to the contrary. But it was not till some ten years ago that the aid of the State was given to the establishment and maintenance of agricultural departments in provincial colleges, and of independent teaching institutions, which should be in a position to supply education and advice to the agricultural community in their district.

The report before us summarises the courses of in. struction, attendance, intra- and extra-mural work, and No. I62 I, voL. 637 financial aspects of each of the eleven English and Welsh collegiate departments and teaching institutions that divide amongst them $7750 l$. of the Board's grants. The grants to Scotland have, since 1896 , been paid through the Scotch Education Office, so that the work of North Britain does not come within the purview of the Board's report.

Within certain limits, each institution is allowed to administer its grant and organise its work on the lines that experience has shown to be most consistent with local requirements. As a result, we find considerable variety in the educational ramifications of the different centres, though this variety is less pronounced now than formerly. Practically all the colleges receiving the Board's grants have arranged courses of instruction, extending over two or three years, which lead up to a certificate, diploma or degree. In addition to these extended courses, most of the colleges are now holding short courses of six to ten weeks, which are specially designed to meet the wants of young farmers who cannot be spared from home for a longer period. Such classes have proved most useful in America and on the Continent, and they are also being well attended in this country.

A prominent feature of the work of all the colleges is the conduct of field demonstrations and experiments, of which a condensed account is given in the second section of the appendix of the Report under notice. This form of educational work was vigorously prosecuted by Young and Marshall in the latter half of last century, and, in the face of a mild undercurrent of opposition, it has been continued ever since. It is a form of educational activity that has been largely developed in the United States, in Canada and on the Continent, so that it may fairly be urged that, whatever its weaknesses, it has, on the whole, gained extensive adoption by reason of intrinsic merit. The objectors to this form of education, or means of agricultural improvement, base their opposition on the following grounds :-

(I) The difficulty of getting a series of plots on soil of equal quality.

(2) The danger of applying results obtained on one farm to the agricultural practice of another.

(3) The possible interference with results of extraneous causes, e.g., birds, mammals, insects, diseases, weather.

(4) The misinterpretation of the value of purely quantitative results.

No doubt the usefulness of field trials may be marred, or worse, by failure under these heads, but the exercise of ordinary care in selecting the land, the rejection of results that have manifestly been unduly influenced by extraneous causes, and, above all, the frequent repetition, both as regards place and season, of the experiments, must in the end furnish a set of figures that cannot fail to prove a useful guide in agricultural practice. If one nay not indulge in wide generalisation from even a considerable number of concrete cases, that is no valid argument against field trials. On the contrary, it is fair to say that if there are a large number of soils that require special treatment, it is the more necessary that farmers should be made familiar with the arrangements and method of field trials, in order that they may, by their aid, inquire into the manurial and other requirements of their own land. In point of fact it is probable that therein lies the main value of such work. No one, who has given. careful heed to the experimental results of past years, will deny that, at least under certain conditions of soil, some very striking and unexpected results have been obtained. Farmers who see such results, recognise that they have made the acquaintance of facts that they would not have anticipated, and they naturally conclude, and rightly, that if the unexpected has 
happened on the farm of a neighbour, it may be that their own practice is not all that could be desired. When once this spirit of inquiry has been roused, a long step forward has been made. But farmers will give attention to work that is going on in their own neighbourhood, under conditions with which they are familiar, when they would not concern themselves with results obtained on a station that they had never seen. For this reason, local experiments and demonstrations would be justified, even if they were no more than a repetition of work conducted elsewhere.

Some curious results have, from time to time, been got with potash, and at no place has this been more conspicuously the case than at the Northumberland Demon. stration Farm of Cockle Park. Speaking generally, and taking the average of several seasons, one finds that, in the North of England, the addition of 3 or $4 \mathrm{cwt}$. of kainit per acre to a nitrogenous-phosphatic artificial dressing increases the turnip or swede crop by about $30 \mathrm{cwt}$. per acre. Such a return is moderately profitable, but not sufficiently so to make it a matter of the first importance, whether north-country farmers use potash for their turnips or not. But not so at Cockle Park, where the arable land is a light loam overlying millstone grit. At that station, potash has proved to be absolutely indispensable in the growth of root crops, so much so, in fact, that, without the support of potash, other manurial elements have practically no effect. The figures for turnips-in terms of an acre-for three years are as follows : -

\begin{tabular}{|c|c|c|c|c|c|c|c|}
\hline Treatment of crop. & $\begin{array}{c}18 \\
\cdots \\
\text { Tons }\end{array}$ & $\begin{array}{l}96 \\
\text { Cwt. } \\
\text { Cwt. }\end{array}$ & \begin{tabular}{|c|c} 
& \\
1 & \\
1 & - \\
Tons
\end{tabular} & $\begin{array}{l}97 \\
C_{w t}\end{array}$ & & ns. & $\begin{array}{l}3 \\
\text { Cwt. }\end{array}$ \\
\hline $\begin{array}{l}\text { Unmanured } \ldots \\
\text { Nitrngen and phosphoric acid, } \\
\text { no potash } \ldots \quad \ldots \\
\text { Nitrogen and phosphoric acid, } \\
\text { with potash .. ... }\end{array}$ & $\begin{array}{l}19 \\
16 \\
26\end{array}$ & $\begin{array}{r}19 \\
17 \\
3\end{array}$ & $\begin{array}{c}2 \\
4 \\
4 \\
14\end{array}$ & $\begin{array}{l}10 \\
17 \\
10\end{array}$ & 1 & 8 & 2 \\
\hline
\end{tabular}

During two of the seasons the crop was actually injured by the use of nitrogen (in the form of sulphate of ammonia) and phosphoric acid (in the form of superphosphate of lime) unsupported by potash. Similar results have been got by at least one foreign investigator by means of water-cultures, and it would be interesting to have an explanation of this curious phenomenon. But, without any explanation, the many hundreds of farmers who have seen these demonstrations have at once perceived that, on land of this character, large expenditure on manures may be absolutely profitless; and they have gone home with the determination to experiment on their own land, in order to ascertain whether their system of manuring is as rational as it might be.

To show how unsafe it is to apply, generally, results obtained with one class of plant, attention may be directed to some experiments begun in 1897 on a permanent meadow, situated within a few hundred yards of the three fields in which the turnip experiments were conducted. The soil of this meadow is somewhat more argillaceous than that of the arable land, but from the appearance of the soil, and in view of the results referred to above, one would not expect that the herbage growing upon it would be absolutely independent of artificial supplies of potash. And yet four years' results have shown that not only does potash fail to increase the yield, but that, when used unsupported by phosphate, it does positive harm. The figures are as follows, the sulphate of potash, which was applied each year, supplying $50 \mathrm{lbs}$. of potash per acre :-

No. 1621 , voL. 637

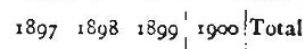

Treatment. Cwt. Cwt. Cwt. Cwt. Cwt.

\begin{tabular}{llllll|lll|l|l} 
Cnmanured & $\ldots$ & $\ldots$ & $\ldots$ & $\ldots$ & $\ldots$ & $22 \frac{1}{2}$ & $27 \frac{1}{2}$ & $19 \frac{1}{2}$ & 20 & $89 \frac{1}{2}$
\end{tabular}

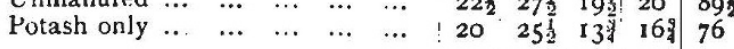

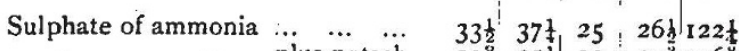

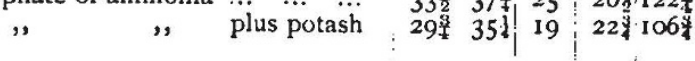

\begin{tabular}{llllll|lll|l} 
Phosphate $\ldots$ & $\ldots$ & $\ldots$ & $\ldots$ & $\ldots$ & 25 & 321 & 231 & 27 & $107 \frac{1}{2}$
\end{tabular}

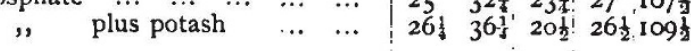

Ammonia and phosphate

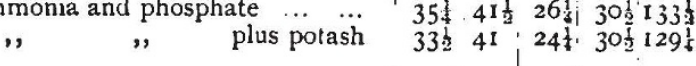

Without any exception, the potash has invariably reduced the yield $(a)$ when used alone, and $(b)$ when added to a nitrogenous manure. This depressing influence is more pronounced in the last two than in the first two years, a result doubtiess due to the accumulation of potash in the soil. When used along with phosphate, the potash slightly increased the yield in the first two years, whereas it has reduced it in the last two. Finally, when added to both nitrogen and phosphate, the action of the potash has either been harmful, or, at the best, negative.

These results not only come out in weighing the crops, but they are precisely what one would anticipate from the general appearance of the plants. In the case of turnips, the plants that have received no potash are of an unhealthy green colour. The leaves are shrivelled and puckered, and covered by large yellow blotches. In the case of the meadow plots that have received potash, without phosphates, the herbage is pale, almost brownishgreen in colour. In other parts of the country this poisonous influence of potash on the mixed herbage of meadows has been observed, Mr. Wood, for instance, having recorded several cases in the east of England. It is evidently a subject of some scientific interest, and worthy of further investigation.

In the past, the agricultural experiments and demonstrations conducted by the local colleges and other institutions subsidised by the Board of Agriculture h.we been chiefly concerned with the manuring of land, though a considerable amount of work has, in the aggregate, been done in the direction of (a) testing new varieties of plants; (b) dealing with insect and fungoid injuries, and the eradication of weeds, notably charlock; $(i)$ the rearing and feeding of stock; $(d)$ dairying; $(e)$ cider manufacture. The initiation of such work has, with few exceptions, been left entirely in the hands of the staff at the various centres, and while much is to be said in favour of this system, there is a good deal to be urged against it. More particularly it is apparent that the lack of any central control, or, it may be, the want of oppurtunities for consultation among the workers, has enyendered a certain amount of unnecessary confusion, which could easily have been avoided with advantage to every one. While one worker uses jo lbs. of phosphoric acid, another, perhaps, uses $6 ; \mathrm{lbs}$., while a third may use 3 cwt. of some phosphate without regard to its contents of phosphoric acid. This means all-round waste of energy, and renders definite comparison of the results impossible.

By voluntary association, one special four-course rotation experiment is being carried out by the Durham College of Science, the Yorkshire College, Cambridge University, the South-Eastern Agricultural College and Nottingham University College. The present season will see the close of this experiment at three of the centres, and the results are likely to be much more valuable than if the work had been entirely uncoordinated. Major Craigie, in his report, directs special attention to this experiment, as also to the fact that the Board has 
made arrangements for the repetition in the south and centre of England of the Northumberland "manuring for mutton " experiment. This work, started in the spring of 1897 , took the form of determining the results of the manurial treatment of grass land, not in terms of hay, but in the terms of live-weight increase. Ten three-acre plots were fenced off on a large field of poor pasture, and nine of these plots were subjected to as many distinct forms of treatinent. The plots have each year been grazed by sheep, each plot being stocked with as many animals as a committee of practical farmers considered it would carry. The individual weights of the animals are determined by monthly weighings. During the first season (1897) variations in the yield of animal increase were fairly pronounced; while in the second, third and fourth years the results have been extremely striking. Lime, used alone, has almost failed to act ; while phosphates, especially basic slag, have, in some cases, enabled the land to carry twice as many sheep as the untreated area, and not only so, but the animals have given more than double the individual live-weight increase. The addition of sulphate of ammonia or potash to a phosphatic dress. ing has had extremely little influence, whereas the beneficial effects of a similar addition of pulverised lime have been very conspicuous. The yield of hay on separate sub-plots gave but a modified reflection of the mutton results, showing that the manures have had much more influence on the quality than on the quantity of the herbage. By a single expenditure of about twenty shillings per acre on manure, it has been shown that land worth five shillings per acre per annum has been-temporarily at least-raised in value to five or six times this sum. Whether such a result will be obtained in other parts of the country it would be hazardous to predict, but there can be no question of the desirability of putting the matter to the test, and it is satisfactory to find that the Board has made arrangements to do so.

The past ten years may be regarded as a period of adjustment in the history of the provincial agricultural colleges. They were called into being as a result of the sudden endowment of county councils with large funds, and practically no preparations had been made for their reception. They were placed in the receipt of grants from public bodies, and these bodies naturally wanted results for their money. If these results could be made to loom large in the eyes of the county council electorate, so much the better. The success of a local lecture was judged rather by the size of the audience than by any educational standard. The county councils vied with each other as to the number of field demonstrations they could show. But things are different now. Both colleges and county councils have elaborated educational schemes, and work will in the future be tested by its intrinsic quality. Now that the feverish incentive to the production of results has been replaced by a demand for thoroughness, it is to be hoped that the colleges will be allowed to settle down to do some first-class work. But, with the best intentions, county councils sometimes handicap the staff of the institutions that they support. It is quite impossible that a department of agriculture can develop in such a way as to do justice to its students, or to take its proper place amongst the other departments of a college or University if a large portion of the time of the members of its staff has to be spent away from headquarters. The local work that they are doing may be of the greatest importance, but the time occupied in its preparation and accomplishment makes a serious inroad on the efficiency of in-college work. It is to be hoped that county councils will give their support to central institutions without being too exacting in their local demands upon them, while the Board of Agriculture should be endowed with funds sufficient to enable the agricultural departments of the colleges to prosecute the highest forms of research.

W.M. SOMERVIILE.

\section{HORTICULTURAL PRACTICE.}

NE method by which the gardener "improves" particular plants was well illustrated at the Hybridisation Conference held in the gardens of the Royal Hortıcultural Society last year. The proceedings of that meeting were amply recorded in these columns at the time, so that there is no need to do more than mention that branch of the subject. Another method of improvement consists in the continuous selection of the best and the cotemporaneous elimination of inferior varieties. This is the method followed by the great seed-firms, who devote large areas to their trial grounds and take the greatest pains to secure and maintain the purity of their stocks. A variation may arise from seed or from "sports," the latter term being applied to bud-variations which occur suddenly, no one knows why. If the variation be a desirable one, the cultivator preserves the seed, sows it, and in due time finds that a certain percentage of the seedlings reproduces the desired form. Further sowings take place, the percentage of the new variation being constantly increased till at length the seeds are said "to come true," and a new species, at any rate so far as gardens are concerned, is evolved by the constant practice of selection.

In the case of a sport, propagation is effected by cuttings or grafts

The advent of the Chrysanthemum season reminds us of other practices which the gardener adopts with the view of securing "improvement." Those who visited the recent exhibitions at the Royal Horticultural Society and at the Westminster Aquarium must have been forcibly struck with the contrast between the wild Chinese Chrysanthemum and the Japanese varieties, which constituted the essential part of the exhibition. The wild plant, sent from the Royal Gardens, Kew, was discovered in central China. Horticulturally it was but a poor weed, with small yellow flower-heads about half an inch in diameter, by no means so attractive as our own cornmarigold. Yet from this plant, either alone or when crossed with another species, the Chinese and the Japanese have evolved flowers of every shade of colour except blue, and the gardener has produced flowers I 5 and 18 inches in diameter.

The Japanese varieties, originally intrc duced by Fortune in 1862 , at once attracted attention by their large size and fantastic form. It is these Japanese varieties that now constitute the staple of our exhibitions, and their size and colour offer, as we have said, the greatest pos sible contrast to the inconspicuous flowers of the wild plant. They are purely artificial productions, and nothing like them occurs in nature, although occasionally, in Composites, malformations occur in the ray-florets which give a clue to the origin of these strange productions.

It is mainly to the art of the gardener that we owe these monstrous blooms. That art consists essentially in "disbudding" or in removing certain buds and leaving others. As the history is interesting and not generally known in scientific circles, it may be well briefly to summarise the facts of the case. The "first break" or lateral bud of a Chrysanthemum nakes its appearance from the middle of April to the middle of June, the precise period differing in the case of different varieties. The second or "crown" bud appears in August, and consists of a flower-bud surrounded by leafy shoots, which grow sympodially; these are removed, and the development of the central flower-bud allowed to proceed. The third or "terminal" bud is formed in September, and always consists of one central bud surrounded by other secondary flower-buds, but not by any leaf-shoots. The secondary flower-buds are removed, and all the energy of the plant concentrated in the central bud, which, in florists' language, is "taken," or, more correctly, which is reserved.

NO. I62 I, VOL. 63] 